\title{
DEVELOPMENT FACTORS FOR DIGITAL TRANSFORMATION OF BANKING AND TRANSPORT INFRASTRUCTURE OF UKRAINE
}

\author{
Liudmyla Shemaieva ${ }^{1}$, Dmytro Hladkykh ${ }^{2}$, Volodymyr Shemayev ${ }^{3}$ \\ ${ }^{I}$ Doctor of Science (Economics), Professor, Senior Consultant of the Department of Economic Strategy, \\ National Institute for Strategic Studies, Kyiv, Ukraine, e-mail: shemayeva@ukr.net; ORCID: \\ https://orcid.org/0000-0002-2989-0823 \\ ${ }^{2}$ Doctor of Sciences (Economics), Associate Professor, Senior Consultant of the Department of Economic \\ Strategy, National Institute for Strategic Studies; Kyiv, Ukraine; e-mail: dgladkikh@ukr.net; ORCID: \\ https://orcid.org/0000-0001-5276-5521 \\ ${ }^{3}$ Doctor of Science (Economics), Professor of Economic Theory Department, National Aviation University \\ Kyiv, Ukraine; (+38)050-953-54-88; e-mail:v.shemayev@gmail.com; ORCID: https://orcid.org/0000-0001- \\ 5599-3941
}

The study examines the problem of the dual impact of the digital economy on various sectors of the economy in the context of insufficient development of the digital infrastructure of Ukraine. The purpose of the study is to determine the factors of the digital economy that either positively or negatively affect the development of banking and transport infrastructure of Ukraine. New opportunities for banks to develop their digital infrastructure have been identified, in particular: increasing the efficiency of their activities by expanding customer base and increasing sales of services, conquering new market segments without the need to opening new "points of sale", increasing revenues, reducing operating costs, rentign and maintenaning premises, optimizing staff and payroll, increasing the level of process automation, accelerating information processing etc. Essenatially, new banking risks associated with the rapid development of the digital economy include: risks associated with the development of non-cash payments, spread of cryptocurrencies and electronic credit platforms, etc. The peculiarities of creation of transport SMART-infrastructure in Ukraine are determined (and the following steps a state should take with the use of public-private partnership in this direction are substantiated).

The impact of the digital economy on the prospects for the development of various sectors of the economy is dual: on the one hand it contains favorable opportunities for such development, on the other - may lead to risks and threats to functioning and development of the economy. Such an impact can be characterized as direct and indirect.

In particular, the World Bank's review entitled "Digital Dividends" [1] provides the following benefits for the development of the digital economy for the country: increased productivity; increasing the competitiveness of companies; creation of new jobs; reduction of production costs; overcoming poverty and social inequality.

Instead, introduction of the digital economy and e-commerce, from the World Bank point of view, carries a number of risks, including: the risk of cyber threats 
associated with the problem of personal data protection; digital "slavery", or the use of personal data of millions of consumers to control and/or manipulate their behavior; rising unemployment due to disappearance of some professions and even industries due to the further spread of information technology and products, including shops with electronic cash registers, bots serving customers, unmanned vehicles, etc. In particular, a number of experts believe that the banking system may disappear in the next ten years; digital divide in education due to different conditions of access to digital services and products, and, as a consequence, gap in the level of consumption of people from the same country or from different countries.

Another classification of risks associated with the development of the digital economy identifies the following key groups of risks [2]: risks of sovereignty (penetration of "foreign" IT technologies into all aspects of life and activities of a country, which significantly increases its vulnerability; finance, transport and energy infrastructure, social engineering and modeling); risks to society (robotization of production and services increases the level of unemployment and the disappearance of certain professions, which exacerbates social disharmony; impoverishment of human and human resources); risks to an individual (computerization from early childhood leads to the development of children's "machine" or "clip" thinking due to the loss of systemic thinking; therefore, there is a gradual process of loss of human identity; instead, the development of innovative breakthrough ideas as a rule, at the junction of different areas of knowledge, requires a nonlinear logic from an idividual).

One of the peculiarities of Ukrainian digital development is that users and businesses are significantly ahead of the state and certain industry. Small and medium-sized businesses already work on the Internet in one way or another and mostly use digital methods to promote their services. At the same time, Ukraine has an underdeveloped infrastructure, low technological education and a general syndrome of "outdated technologies". First of all, the country needs to improve the quality of digital infrastructure, which is developed at all in Ukraine at low level.

The development of the digital infrastructure of the state is necessary for the transformation of all spheres of life, giving them a significant economic and social effect. Further, we examine the example of banking and transport infrastructure factors influencing digital transformation in Ukraine.

1. Banking infrastructure. Further, we examine the example of banking and transport infrastructure factors influencing digital transformation in Ukraine through the prism of "benefits-risks":

- the change in the structure of the banking system of Ukraine and the nature of the regulator's activities under the influence of digital economy, in accordance with global trends, is manifested, in particular, in: 
successful completion of testing of own digital currency. As part of testing the experience of other Central Banks during 2016-2018, the National Bank of Ukraine (NBU, regulator) introduced a digital e-hryvnia in a pilot mode, which is considered as an alternative to existing payment instruments (cash, payment cards and electronic money). The advantages of e-hryvnia are: ease of use, availability, security (due to the guarantees of the NBU) and speed of payments [3]. Instead, the key risk for Ukrainian banks from the full introduction of e-hryvnia is the likelihood of a new product to absorb existing e-money services issued by commercial banks, which will lead to losses of previous costs for the implementation of e-products by reorienting customers to a more reliable a tool offered by NBU;

accelerated provision of financial inclusion, which is one of the strategic goals of NBU [4]. Among the achievements of the regulator in this area, reflected in the NBU Report for 2018 was an increase, by one third y-o-y, of payment card transactions and an increase in the share of non-cash transactions among all transactions using payment cards to $45 \%$ [5];

intensification of the regulator's efforts aimed at improving financial literacy of the society, which is one of the key areas of financial inclusion. According to the USAID study "Financial Literacy, Financial Inclusion and Financial Welfare in Ukraine", Ukraine's financial literacy rate is 11.2 out of a maximum of 21, the lowest among the 30 countries surveyed by the OECD in 2016 [6];

reducing the number of operating bank branches, which is associated with the automation of banking operations and the spread of online sales of banking products, which allows banks to optimize the network and reduce "traditional" banking staff (cashiers, operators, credit inspectors, collectors, security guards, etc.);

emergence of virtual "banks without branches". This includes the entry into the banking services market at the end of 2017 of the new Monobank structure. At the same time, this institution does not have a license from the NBU to carry out banking activities, the reporting of the "bank" is not published by the NBU, its assets and liabilities are accounted for on the balance sheet of JSC "Universal Bank". Thus, Monobank is an Internet banking project consisting of a mobile application and a credit card issued by JSC Universal Bank. Monobank customers receive consumer lending services, and the issuance, maintenance and re-issuance of the card in case of loss is free. Card payments provide for the possibility of "cashback" of up to $20 \%$ depending on the transaction. Users of the mobile application also have access to transfers between individuals, utility payments, mobile account replenishment, payment of fines, taxes, single social contribution, online games, other types of payments and support in messengers (Viber, Telegram, Facebook Messenger) [7];

spreading the presence in the Ukrainian banking market of new entities that are not banks in nature, but perform "traditional" functions of banks related to money 
transfers, currency sales and lending (non-banking payment systems that transfer funds: GlobalMoney, City24, Ukrkart, etc.; microfinance organizations that provide online loans: moneyveo.ua, moneyboom.com.ua, online-groshi.com, etc.; P2Plending services, in particular, Pozychaiko, finhub.ua, taplend.com, cryptocurrency sales services: Tyme and IBox terminals [8], specialized cryptocurrencies [9], online exchange offices, in particular, Bitcoin24 [10], which works with the help of Privat 24, and others [11], online exchanges kuna.io and btc.trade [12]);

active expansion of the bank's payment infrastructure (ATMs, payment and POS terminals) outside banks and bank branches, which actualizes the risks associated with physical security and cybersecurity;

- changes in the operational component of banking under the influence of the digital economy form, in particular, the following trends:

reduction of the share of cash payments, development of the infrastructure of non-cash payments and electronic banking. The use of non-cash payment and ebanking tools provides banks with a number of advantages and opportunities, including expanding the list and increasing sales of services, thus significantly increasing revenues and reducing operating costs for recalculation, examination of damaged and questionable banknotes, security, collection, lease and maintenance of premises, optimize the number of employees (respectively - the cost of wages).

The key risks associated with the active development of non-cash payments and e-banking include [13]: cyber risks, including hacker attacks, software and hardware "bookmarks" in hardware, electronic espionage, exploitation vulnerabilities in obsolete equipment; risk of fraud, primarily with payment cards [14], risk of liquidity, which is manifested in the volatility of balances on passive accounts due to cyberattacks; operational risk, which is manifested in the interruption of business processes due to staff errors, process errors, technological causes, internal and external fraud, external influences (eg, power outages); strategic risk, which is exacerbated by the imperfect plan of innovative development of the bank, which can lead to unjustified growth of costs, which provokes low profitability or unprofitability of digital banking; reputational risk that may be caused by negative public opinion about the bank, which is immediately spread through electronic media and/or social networks and leads to an outflow of customers and liabilities; legal risk resulting from violations by banks of regulatory documents governing activities in the field of electronic banking;

- distribution of cryptocurrencies. Characterization of cryptocurrencies as a fundamentally new type of money causes a radical change in the rules of the game in business and change the principles of interaction between banks, businesses and individuals. This is the case, in particular, in both Ukrainian (A. Dyka [15], T. Zhelyuk [16], R. Baranov [17]) and foreign (J. Tarud [18], E. Estebed [19], D. Kevry 
[20]) works. The advantages of using cryptocurrencies are: no dependence of service provision on working (banking) days; complete anonymity; the potential for simplification and acceleration of international settlements, including the use of banking infrastructure; potential possibility for banks to receive additional income through active-passive operations using cryptocurrencies and commissions for intermediary services.

The risks associated with the use of cryptocurrencies are as follows [21]: undermining the monetary monopoly of the state; reduction of central bank seigniorage; reduction of demand for the national currency, which causes its depreciation and change in the speed of circulation, which complicates the implementation of monetary regulation; the impossibility of conducting an effective monetary policy, as a significant part of the money supply will be beyond the control of the regulator; reduction of the level of influence or elimination of financial intermediaries (first of all - banks); destabilization of the financial market in general due to the fall of the cryptocurrency market; penetration into the domestic market of foreign financial institutions as a result of intensified competition and loss of market position by national institutions, which provokes the loss of monetary sovereignty of the country; use for money laundering, "capital flight" abroad, concealment of corrupt sources of wealth, illegal transactions; anonymity of the transaction process; uncertainty of the objective value of cryptocurrencies, which should be expressed in real goods and services; the contradiction between the issue and the real demand for virtual currency; lack of state guarantee, which makes it impossible to safely accumulate cryptocurrency; zero intrinsic value, which means the possibility of becoming a "financial bubble"; threats to the environment due to unproductive electricity consumption; high exchange rate volatility; lack of guarantees for the safety of electronic cryptocurrencies (risk of loss of funds due to loss of password to the electronic cryptocurrency or its inoperability); the possibility of repressive actions by regulators; falling profitability of mining; the possibility of "electronic robbery";

- development of electronic credit platforms. These are companies that determine the solvency of a person or company instead of banks, after which there is an investor who wants to allocate funds for lending. This form of credit relations in the long run is able to oust banks from the credit market, leaving them without interest income, which currently accounts for the lion's share (about 70-80\%) of gross income of the banking system, and taking away the share of cash flows forming bank assets and liabilities.

Among the advantages and opportunities provided by banks involved in the promotion of P2P platforms: no liquidity risk, because the bank does not use for lending or its own funds or borrowings; no risk of loan default; the possibility of obtaining additional income in the form of commissions; gaining access to an 
additional customer base and the ability to sell them additional services [22]. The main risks to the development of $\mathrm{P} 2 \mathrm{P}$ lending in Ukraine are: $\mathrm{P} 2 \mathrm{P}$ lending platforms, which operate with the participation of banks, are based on the internal rules of the banks themselves, but are not regulated by the NBU and the Law of Ukraine "On Banks and Banking"; there is no legislative regulation of the liability of intermediaries, therefore, the rights of the person who is a creditor in this scheme are not protected; deposits are also not guaranteed by the state Fund for guaranteeing deposits of physical assets, which increases the risk of losing funds; P2P lending transactions are not subject to reporting to the NBU, so the regulator does not have the ability to monitor, analyze and regulate these transactions [23]. Instead, the NBU identifies the following among the risks of lending: lending to borrowers, whose credit risk is determined by the policy of banks and is not regulated by the NBU; low level of awareness of the population about possible losses; the possibility of lending to related parties; failure to reflect these transactions in the reporting of banks [24];

- Vulnerability of digital infrastructure used by banks. Today in Ukraine there is no standardized software product under the conditional name "Bank Operations Day". Therefore, each institution uses those software modules that are suitable for a particular bank in terms of price and functionality. The large number of platforms and different types of software leads to problems that complicate mergers and acquisitions of banks, as well as to the increased vulnerability of banks to the actions of criminals, hacker attacks, identity theft, computer viruses and more.

In summary, it should be noted that the impact of the digital economy on the prospects of the country's banking system and infrastructure is manifested, in particular, in the emergence of a wide range of new opportunities for such development, on the other hand, carries a large number of fundamentally new risks.

2. Peculiarities of creation of transport SMART-infrastructure in Ukraine. An important area in which the international infrastructure is adapting to the challenges of the digital economy is the active implementation of the concept of "smart cities", which began in 2008 after the financial crisis. Today, there are entire cities running on the Smart system. According to McKinsey's forecast, they will generate at least two-thirds of the world's GDP. The concept of a "smart city" does not have a typical generally accepted definition or set of terms to explain it.

In 2014, the report of the International Telecommunication Union considered more than 100 definitions related to smart cities, and the result of this analysis was the following definition: "A sustainable smart city is an innovative city that uses ICT and other means to improve the quality of life, efficiency of activities and services in cities, as well as competitiveness in meeting the needs of present and future generations in economic, social and environmental aspects". 
The application of the smart city concept opens up significant opportunities for different countries: in developing countries, cities feel an urgent need to create an adequate urban infrastructure that would meet the growing pace of urbanization. In the process of satisfying infrastructural demands, various types of smart infrastructure applications open up the possibility for such cities to make a technological breakthrough.

Developed countries often face the problem of maintaining the functionality of outdated infrastructure, which cannot be abandoned due to cost, territorial and other considerations.

In such countries, ways of applying smart city technologies can be aimed primarily at promoting the optimal operation of existing infrastructure and monitoring the functioning of old resources of this kind. However, in both developing and developed countries, the main argument in favor of using smart infrastructure should be that they meet society's needs for sustainable development.

The smart infrastructure of the city is the basis for all major aspects of living in it, including the rational behavior of the population, rational mobility, rational economy, rational way of life, rational management and rational use of the environment. The main feature that underlies most of these components is their interconnectedness and data generation, which can be rationally used to ensure optimal resource consumption and increase efficiency.

In Ukraine, the proliferation of SMART-infrastructure in the cities is confidently taking the first steps: certain Smart City projects are being implemented at the initiative of the state or business: fare payment in the metro, trams and funiculars of Kyiv, GPS in public transport, electronic queue at medical clinics, etc. Authorities in other Ukrainian cities also open up space for the implementation of certain Smart City projects such as Lviv, Odesa and the region, Dnipro, Sumy, and others. In Western Ukraine, UNDP funds projects for the digitalization of smaller towns, sich as Kalush, Ivano-Frankivsk, Ternopil and others.

Below we summarize currently available components of SMART-infrastructure in Ukraine:

1) E-services (use of information and communication technologies in various fields): provision of administrative services; discussion of regulations and more. The advantages of providing electronic services are:

- convenience of receiving electronic services; accessibility and transparency of the rules for their provision;

- no queues - saving the applicant time;

- convenient forms of electronic applications;

- wide and dynamic scope of electronic services;

- ability to control the progress of electronic services; 
- ensuring a high degree of information security of the applicant's personal data on service portals;

- transparency of state activity; increasing the availability of services and openness of state data (activity of involving citizens in the activities of the state with a reduction of their time and financial costs);

2) E-ticket - creating a single window system for selling tickets for any mode of transport with the ability to combine modes of transport. Advantages of the electronic ticket:

- saving time when buying a ticket via the Internet;

- possibility to choose combined routes from different types of transport;

- storage of the ticket in electronic form in a database that protects against loss, theft or absence of a paper ticket;

- the opportunity to buy a ticket for other people who are in another city or for other reasons do not have the opportunity to buy a ticket, they only have to come to the registration;

3) implementation of the ERP system in the Ministry of Infrastructure of Ukraine and integration and implementation at relevant state enterprises and organizations, which provides for:

- electronic document management; contractual accounting;

- supply logistics management; accounting calculations;

- management of fixed assets; road repair and maintenance management;

- financial planning and budgeting; accounting and tax accounting; assessment, calculation of material needs;

- accounting of spare parts in warehouses, tracking of balances; personnel management and salary calculation;

4) open budget - creation of conditions for satisfaction of needs of citizens in the information on use of means of the state and local budgets by the Ministry of Infrastructure of Ukraine and the state enterprises which are in the sphere of management of the Ministry. Principles of open budget functioning:

- relevance and reliability of information;

- integration with geographic information systems for ease of search and perception of information provided;

- interactive access to the portal regardless of territorial remoteness;

- convenience of work provided by constant improvements of ergonomic characteristics of a portal.

The advantages of an open budget are: 
- formation of a single open information space in the field of financial management of enterprises and the economy in terms of (financial condition, volume and sources of budget revenues;

- determination of the main priorities and directions of budget expenditures; debt obligations of enterprises);

- creating a positive image and reputation of public authorities and local governments;

- anti-corruption;

- increasing the investment attractiveness of enterprises;

5) open data - automatic coverage of open data registers that are filled in and maintained by state transport enterprises;

- creation of a cyber situational center of the Ministry of Infrastructure of Ukraine, which will provide control over the implementation of the functions assigned to the Ministry in real time, in particular:

- appeal to emergency operational services such as "single window"; reducing the response time of emergency services to public appeals; transfer of geoinformation data for the direction of the nearest brigade of emergency operational services;

- informing and notifying citizens about emergencies in transport, transport infrastructure facilities and crowded places.

Comprehensive collection of information will allow to make effective management decisions and ensure the safety of transportation of citizens and goods.

- E-Post - creation of an online marketplace similar to eVau and a mobile application $\mathrm{mWallet}$, which combines all possible financial services, from digitizing discount cards to $\mathrm{P} 2 \mathrm{P}$ transfers, providing each customer with an ID post and the following services:

- contact center services; ordering tickets (railway, bus, air); money transfers; payment for housing and communal services;

- provision of state administrative services; payment of fines, taxes; provision of insurance policies;

- tracking e-mails; online ordering of periodicals; mobile application service for iOS and Android systems;

- main functions of the personal account of the web portal; push notifications about delivery or changes in service processing statuses;

- service calculator; search for the nearest branch (by location);

- E-transport (air, rail, car, water) - the creation of a single transport model, logistics schemes at different levels, real-time optimization of freight and passenger traffic, traffic flows. The first steps in this direction are related to: 
- conducting an inventory, creating an accounting system and maintaining an upto-date "register" of rolling stock;

- use of relevant information on the movement / transportation of passengers and goods;

- acceptance of operational information on the location of rolling stock;

- creation of a system of analytical processing of aggregate information to assess the cost and commercial efficiency of the work performed.

The measures listed above will prevent improper and inefficient use of rolling stock; create a system of emergency response and notification of emergency situations; create a system for evaluating the effectiveness of the quality of services provided.

The following steps in this direction include:

- introduction of a system for registration of imported containers (electronic order for issuing a container from the port, permission of customs to load the container, permission to leave the checkpoint, transition from paper to electronic document management using EDS, availability of approved technological schemes at the port, integration with the system modern model of system implementation - the presence of elements of open architecture for process configuration (construction of network and computer infrastructure in the port);

- introduction of separate software packages on accounting platforms for cargo accounting in the port, accounting and personnel and salary accounting; introduction of communication with the weight of vehicles for electronic control; introduction of elements of the "Single Window";

- improvement of automated control systems for the process of passenger traffic management with the use of information technology, which requires:

- to introduce a management system for the process of transportation management and commercial work; to equip rolling stock with GPS-systems;

- install information boards at stops;

- to place ticket sales terminals at stops;

- geoinformation systems of real-time geospatial information coverage;

- mobile applications - easy and fast access to systems, the possibility of feedback in electronic form, including e-ticket, e-application, e-petition and others;

- cloud computing and technology-providing universal and convenient access through the network to a common pool of computing resources;

- cybersecurity of implemented systems-protection of vital resources of citizens, society and the state in cyberspace. 


\section{The country's needs for smart urban infrastructure initiatives should be reflected}

in current national policies on national transport infrastructure and ICT. Taking these needs into account involves strengthening a supportive ecosystem that enables the development of smart infrastructure, including human resources, the legal framework, technology policies, institutional arrangements and data use policies at both government and human resources levels.

\section{References:}

1. Digital dividends. Overview. World Bank World Development Report 2016 Retrieved from https://openknowledge.worldbank.org/bitstream/handle/10986/23347/210671RuSum.pdf?sequence=16 (rus). 2. Kupavin G. Digital economy: benefits and risks - a systematic approach Retrieved from https://cont.ws/@doctordragon/740390 (rus).

3. The National Bank will continue to study the possibility of issuing its own digital currency - e-hryvnia. Retrieved from https://bank.gov.ua/control/uk/publish/article?art_id=96166822\&cat_id=55838 (ukr).

4. Strategy of the National Bank of Ukraine. Retrieved from https://bank.gov.ua/doccatalog/document?id=64754192 (ukr).

5. Annual report of the National Bank for 2018: 10 key performance indicators of the Ukrainian central bank for the last year. from https://bank.gov.ua/control/uk/publish/article?art_id=96085949\&cat_id=55838 (ukr).

6. OECD (2016). OECD/INFE International Survey of Adult Financial Literacy Competencies Retrieved from https://www.oecd.org/daf/fin/financial-education/OECD-INFE-International-Survey-of-AdultFInancial-Literacy-Competencies.pdf

7. Monobank Retrieved from https://www.monobank.ua/?lang=uk (ukr).

8. Vlasiuk O. (2017). Financial system of information economy. Strategic panorama. No 2. - p. 9-16. (ukr). 9. Open testing of the cryptocurrency system has started in Ukraine. Retrieved from https://pogliad.ua/news/money/v-ukrayini-startuvalo-vidkrite-testuvannya-sistemi-kriptomativ-342890 (ukr). 10. Bitcoin24. Retrieved from https://bitcoin24.com.ua/?gclid=CMCZz4anotYCFU3gGQod_DIN2g (rus).

11. Bitcoin exchangers monitoring. Retrieved from
https://coinmonitor.io/ru/?utm_source=facebook\&utm_medium=cpc\&utm_campaign=pokaz_po_minibaze_e mail_lookalike (rus).

12. Romanova M. Where to get bitcoin and what to do with it. The main schemes for making money on cryptocurrency. Retrieved from https://strana.ua/articles/109655-kak-kupit-bitkoin-i-hde-vzjat-rukovodstvokak-zarabotat-na-kriptovaljute.html (rus).

13. Oleshko A. (2017) Formation of a non-cash economy in Ukraine - cashless economy. Transformation of financial markets in the conditions of global instability: realities of the present and look into the future. Collection of materials of the field scientific-practical seminar (October 6-15, 2017) and the international scientific-practical Internet conference (October 30, 2017). Irpen: SFSU University. p. 339-341 (ukr).

14. Liamin L. (2010) Risk management problems associated with electronic banking. Banking. No 10. - p. 74-78. (rus).

15. Dika A. (2017). Cryptocurrency in Ukraine: current state and trends. Financial and credit system of Ukraine in the conditions of integration and globalization processes: Proceedings of the XVI All-Ukrainian scientific-practical conference of students and graduate students. April 20-21, 2017 - Cherkasy: University of Banking. - p. 109-112. (ukr).

16. Zheliuk T. (2016). The use of cryptocurrency in the payments market: new opportunities for national economies. Bulletin of Ternopil National Economic University. No 3. - p. 50-60. (ukr).

17. Baranov R. (2015). Countering money laundering and terrorist financing with the use of virtual currencies. Public administration: theory and practice. No 2. - p. 29-37. (ukr).

18. Tarud J. Is Traditional Banking Under Threat from Cryptocurrency? Retrieved from https://www.koombea.com/blog/cryptocurrency.

19. Etsebeth E. Cryptocurrency and Central Banks: The Quest to Dematerialize Money Retrieved from https://www.coindesk.com/central-banks-cryptocurrency-and-the-quest-to-dematerialize-money.

20. Cawrey D. How is regulation going to affect the bitcoin price? Retrieved from https://www.coindesk.com/how-isregulation-going-to-affect-the-bitcoin-price.

21. Panteleeva N (2015). New forms of money in the formation of the information society. Bulletin of the NBU. No 5. p. 25-31. Retrieved from http://bank.gov.ua/doccatalog/document?id=17795590 (ukr). 
22. Will P2P lending become a popular service in Ukrainian banks - expert opinion. Retrieved from http://www.prostobank.ua/potrebitelskie_kredity/stati/stanet_li_P2P_kreditovanie_populyarnoy_uslugoy_v_ ukrainskih_bankah_mnenie_ekspertov (rus).

23. NBU wants to legalize P2P lending in Ukraine. Retrieved from https://personalbanker.com.ua/nbu/1200nbu-khochet-uzakonit-P2P-kreditovanie-v-ukraine (rus).

24. The National Bank initiates the settlement of the issue of P2P lending. Retrieved from http://www.bank.gov.ua/control/uk/publish/article?art_id=30375585 (ukr). 